\title{
Efek Analgetik dan Antiinflamasi Kaempferia Galanga (Kencur)
}

\author{
Putu Nita Cahyawati ${ }^{*}$ \\ ${ }^{1}$ Bagian Farmakologi dan Farmasi Fakultas Kedokteran dan Ilmu Kesehatan, Universitas Warmadewa \\ *putunitacahyawati@gmail.com
}

\begin{abstract}
ABSTRAK
Kaempferia galanga (K. galanga) atau yang dikenal sebagai "kencur" di Indonesia digunakan sebagai salah satu bahan makanan. Tanaman ini sering dijadikan pasta karena dipercaya dapat mengatasi kelelahan. Berdasarkan hasil review, secara tradisonal tanaman ini sering digunakan untuk pengobatan diare, migrain dan meningkatkan energi, dan mengatasi kelelahan. ${ }^{1}$ Rimpang K. galanga selama ini digunakan oleh untuk menghilangkan sakit gigi, sakit perut, pembengkakan pada otot dan rematik. K. Galanga secara luas juga digunakan di Thailand untuk pengobatan hipertensi, asma, rematik, gagngguan pencernaan, demam, sakit kepala dan mengurangi rasa nyeri abdomen. ${ }^{2,3}$

Kaempferia galanga termasuk dalam kingdom: Plantae, sub kingdom: Phanerogamae, divisi: Spermatophyta, sub divisi: Angiospermae, kelas: Monocotyledonae, seri: Epigynae, ordo: Scitaminales, keluarga: Zingiberaceae, genus: Kaempferiam, spesies : galanga. Bagian tanaman yang sering digunakan adalah rimpang, akar, daun. ${ }^{1}$

Komponen utama yang terkandung dalam K. galanga antara lain ethyl-p-methoxycinnamate (31.77\%), methylcinnamate (23.23\%), carvone (11.13\%), eucalyptol (9.59\%) dan pentadecane (6.41\%). Ekstrak K.galanga dilaporkan memiliki efek antinflamasi, analgetik, antidiare, antibakteri, sedatif, sitotoksik, insektisidal, antihelmint, dan antioksidan. ${ }^{4,5}$
\end{abstract}

\section{Efek Analgesik dan Antiinflamasi}

Suatu studi melaporkan bahwa ekstrak metanol K. Galanga secara nyata menunjukkan efek antinosiseptik pada hewan percobaan. Mekanisme antinosiseptik ini kemungkinan melibatkan reseptor opioid dan dimediasi oleh aktivitas sistem saraf pusat dan perifer. Pada pengujian ini dosis ektrak yang digunakan antara lain 50, 100 dan $200 \mathrm{mg} / \mathrm{kg} .{ }^{6}$ Efek analgesik juga dievaluasi menggunakan model hot plate dan tail-flick. Pada studi ini disimpulkan bahwa K. galanga memiliki aktivitas analgesik yang juga dimediasi oleh aktivitas sistem saraf pusat (spinal dan supraspinal) serta melibatkan reseptor opioid. Penggunaan model tail flick dipercaya dangat berkorelasi dengan persepsi nyeri pada manusia. ${ }^{7}$ Aktivitas analgesik yang sama juga ditunjukkan pada hewan uji dengan menggunakan tes menggeliat (writhing test). Kompleks fosfolipid diketahui bertindak sebagai carier (pembawa) yang bisa meningkatkan aktivitas analgesik K. galanga. ${ }^{3}$ 
Disamping efek analgesik, K. galanga juga menunjukkan efek antiinflamasi pada model karaginan. ${ }^{7}$ Studi pada ekstrak K. galanga yang dibuat menjad bentuk plester juga menemukan bahwa ekstrak ini dapat berfungsi sebagai antiinflamasi karena mampu mengurangi peradangan akut pada tikus. ${ }^{8}$ Efek ini kemungkinan diperoleh akibat penghambatan pada enzim cyclooxygenase dan penghambatan sintesis prostaglandin. ${ }^{7}$ Dari semua ekstrak K. galanga, petroleum ether extract adalah yang paling efektif dalam menekan progresi inflamasi akut dan kronik pada tikus melalui penghambatan pada infiltrasi neutrofil. ${ }^{9}$

Disamping itu, K. galanga juga dilaporkan mampu menghambat produksi reactive oxigen species (ROS) intraseluler. Ethyl-p-methoxycinnamate (EPMC) yang diisolasi dari K. Galanga dipercaya bertanggung jawab terhadap efek protektif terhadap kerusakan oksidatif ini. ${ }^{10}$ Ethyl-pmethoxycinnamate juga mampu menghambat inflamasi melalui penekanan kadar interleukin 1, tumor necrosis factor-a, dan angigenesis melalui penekanan pada fungsi sel endotel. ${ }^{11}$

Ethyl cinnamate (EC) yang juga diisolasi dari rimpang $\mathrm{K}$. galanga mampu menghambat kontraksi tonus yang diinduksi oleh peningkatan kadar $\mathrm{K}^{+}$dan phenylephrine (PE) dengan nilai $\mathrm{IC}_{50} 0.30 \pm 0.05 \mathrm{mM}$ and $0.38 \pm 0.04 \mathrm{mM}$. Ethyl cinnamate juga mampu menghambat masukknya $\mathrm{Ca}^{2+} \mathrm{ke}$ dalam sel vaskular dan pengeluaran nitrit oxide serta prostasiklin dari sel endotel. Hasil ini menunjuukan bahwa efek vasorelaksasi $\mathrm{K}$. galanga dimediasi melalui jalur yang berbedabeda sehingga menjelaskan pemanfaatan tanaman ini pada kasus hipertensi. ${ }^{12}$

Efek penyebuhan luka oleh K. Galanga juga diuji pada hewan coba. Hasil studi menemukan bahwa ekstrak alkohol K. galanga secara signifikan mempu menurunkan waktu epitelisasi dan memperbaiki keterlambatan epitelisasi yang disebabkan oleh efek dexametason. ${ }^{13}$

Uji klinis ekstrak K. galanga pada 35 sampel penelitian (18 kelompok intervensi dan 17 kontrol) dilaporkan memiliki efektifitas yang sama dengan meloxicam untuk menangani osteoatritis. ${ }^{14}$ Hasil serupa juga ditunjukkan pada penelitian lainnya yang juga menemukan bahwa tidak terdapat perbedaan rasa nyeri, kekakuan dan fungsi fisik pada kelompok perlakuan dengan pemberian ekstrak K. galanga, sehingga dapat diberikan sebagai terapi alternatif pada kasus osteoatritis. ${ }^{15}$

\section{Uji Toksisistas dan Keamanan}

Hasil uji toksisitas akut dan subakut K. Galanga menunjukkan tidak adanya perbedaan abnormalitas pada gambaran histopatologi antar kelompok perlakuan dan jenis kelamin. Tidak ditemukan pula adanya perbedaaan angka kematian, perbedaan berat badan dan berat organ pada kelompok perlakuan. Hasil analisis hematologi menunjukkan tidak adanya perbedaan parameter sel darah putih, platelet, hematokrit, dan hemoglobin. Demikian pula pada hasil analias kimia darah yang juga tidak menunjukkan perbedaan parameter kadar glukosa, blood urea nitrogen (BUN), aspartate 
transaminase (AST), alanine transaminase (ALT), alkaline phosphatase (Alk-P), total protein dan albumin. Hasil pemeriksaan patologi anatomi juga normal dan tidak ditemukan adanya tanda-tanda iritasi pada kulit. ${ }^{16}$ Penelitian lain juga melaporkan bahwa K. galanga terbukti aman dan tergolong dalam tanaman yang memiliki nilai energi tinggi disertai efek kemopreventif tanpa bahan fitokimia yang beracun dan dapat ditoleransi. Analisis komponen makro dan mikro nutrien mengkonfirmasi K. galanga memang mengandung protein, fiber dan kaya akan mineral esensial seperti potasium, fosfor, dan magnesium, serta mengandung besi, mangan zink, cobalt dan nikel. ${ }^{10}$

Akan tetapi, studi lain melaporkan bahwa K. galanga dan komponen aktifnya (ethyl-p-methoxycinnamate) kemungkinan terkait dengan adanya interaksi antara tanaman herbal dan obat, serta meningkatkan risiko toksisitas dan karsinogenesis dari suatu obat dan komponen yang dimetabolisme oleh CYP1A1, CYP2B dan CYP2E1. ${ }^{2}$

\section{Kesimpulan}

Berdasarkan data-data di atas, diketahui bahwa K. galanga memiliki efek analgetik dan antiinflamasi. Akan tetapi, karena mayoritas penelitian masih terbatas pada penelitian in vitro dan in vivo efek yang ditimbulkan pada manusia belum dapat dipastikan. Selain itu, meskipun belum ada laporan efek toksik pada hewan, karena keterbatasan jumlah penelitian pada manusia, pemanfaatan dalam jumlah besar dan secara luas di masyarakat juga harus lebih hati-hati karena kemungkinan timbulnya interaksi antara obat maupun komponen makanan lainnya.

\section{Referensi}

1. Preetha TS, Hemanthakumar AS, Krishnan PN. A comprehensive review of Kaempferia galanga L. (Zingiberaceae): A high sought medicinal plant in Tropical Asia. Journal of Medicinal Plants Studies. 2016. 4(3): 270-276

2. Sirisangtrakul W. Sripanidkulchai B. Effects of Kaempferia galanga L. and ethyl-p-methoxycinnamate (EPMC) on hepatic microsomal cytochrome P450s enzyme activities in mice. Songklanakarin J. Sci. Technol. 2011. 33 (4):411-417

3. Kusumawati I, Yusuf H. Phospholipid complex as a carrier of kaempferia galanga rhizome extract to improve its analgesic activity. Int J Pharm Pharm Sci. 3(1):44-46

4. Tewtrakul S, Yuenyongsawad S, Kummee S, Atsawajaruwan L. Chemical components and biological activities of volatile oil of Kaempferia galanga Linn. Songklanakarin J. Sci. Technol. 2005. 27 (2):504-507

5. Shetu HJ, Trisha KT, Sikta SA, Anwar R, Rashed SSB, Dash PR. Pharmacological importance of Kaempferia galanga (Zingiberaceae): A mini review. International Journal of 
https://ejournal.warmadewa.ac.id/index.php/wicaksana

Pharmacy and Pharmaceutical Sciences. 2018. 3:32-39.

6. Ridtitid W, Sae-Wong C, Reanmongkol W, Wongnawa M. Antinociceptive activity of the methanolic extract of Kaempferia galanga Linn. in experimental animals. J Ethnopharmacol. 2008. 118(2):22530.

7. Vittalrao AM, Shanbhag T, Kumari KM. Bairy KL, Shenoy S. Evaluation of antiinflammatory and analgesic activities of alcoholic extract of kaempferia galanga in rats. Indian J Physiol Pharmacol 2011. 55 (1) : 13-24

8. Riasari H, Rachmaniar R and Febriani Y: Effectiveness of Anti-Inflammatory Plaster from Kencur (Kaempferia Galanga L.) Rhizome Ethanol Extract. Int J Pharm Sci Res 2016; 7(4): 174649.

9. Jagadish PC, Latha KP, Mudgal J, Nampurath GK. Extraction, characterization and evaluation of Kaempferia galanga L. (Zingiberaceae) rhizome extracts against acute and chronic inflammation in rats. Journal of Ethnopharmacology. 2016. 194: 434439

10. Srivastava N, Ranjana, Singh S, Gupta AC, Shanker K, Bawankule DU, Luqman S. Aromatic ginger (Kaempferia galanga L.) extracts with ameliorative and protective potential as a functional food, beyond its flavor and nutritional benefits. Toxicology Reports. 2019. 6:521-528

11. Umar MI , Asmawi MZ, Sadikun A, Majid AMSA, Al-Suede FSR, Hassan LE, et al. Ethyl-pmethoxycinnamate isolated from kaempferia galanga inhibits inflammation by suppressing interleukin-1, tumor necrosis factor-a, and angiogenesis by blocking endothelial functions. Clinics. 2014. 69 (2):134-144

12. Othman R, Ibrahim H, Ali mohd M, Awang K, Gilani A, Mustafa M. Vasorelaxant Effects of Ethyl Cinnamate Isolated from Kaempferia galanga on Smooth Muscles of the Rat Aorta. Planta medica. 2002. 68(7):6557.

13. Tara VS, Chandrakala S, Sachidananda A, Kurady BL, Smita S, Ganesh S. Wound healing activity of alcoholic extract of kaempferia galanga in wistar rats. Indian J Physiol Pharmacol. 2006. 50(4):384-390

14. Syahruddin AN, Dahlan CK, Taslim NA. The effects of kaempferia galanga 1. extract on pain, stiffness and functional physic in patient with knee osteoarthritis : double blind randomized clinical trial. International Journal of Science \& Healthcare Research. 2017. 2(4): 37-43.

15. Taslim NA, Djide MN, Rifai Y, Syahruddin AN, Rampo YR, Mustamin M, et al. "Double-blind 
randomized clinical trial of kaempferia galanga 1 extract as an antiinflammation (prostaglandin E2 and tumor necrosis factor alpha) on osteoarthritis". Asian Journal of Pharmaceutical and Clinical Research. 2019. 12(5):63-66, doi:10.22159/ajpcr.2019.v12i5.31777.

16. Kanjanapothi D, Panthong A, Lertprasertsuke N, Taesotikul T, Rujjanawate C, Kaewpinit D, et al. Toxicity of crude rhizome extract of Kaempferia galanga L. (Proh Hom). Journal of Ethnopharmacology. 2004. 90(2-3):359-365 